\title{
THE INFLUENCE OF NEW WORLD SPECIES ON THE BOTANY OF THE 16th CENTURY
}

\author{
Andrea Ubrizsy Savoia \\ Dipartamento de Biologia Vegetale - Università di Roma "La Sapienza" \\ P. Le Aldo Moro, 5.00185 Roma
}

\section{RESUMEN}

El presente trabajo analiza cómo algunas especies botánicas del Nuevo mundo, no tan difundidas como el tomate, el tabaco, etc., formaron parte del conocimiento botánico europeo, haciendo especial referencia a la de obra de Ulisse Aldrovandi (1522-1605). Su herbario, sus colecciones iconográficas y manuscritos que contienen listas de semillas, maderas y otros materiales, se conservan en su Museo y algunas de las especies crecen en el Jardín Botánico de Bolonia.

\begin{abstract}
This paper is about how some New World species, not as widespread as tomato, tobacco, etc. were introduced in the botanical European knowledge, with special reference to Ulisse Aldrovandi (1522-1605). His herbal, his inconographic collections and manuscripts containing lists of seeds, woods and other matrials, are conserved in his Museum and grown in the Botanical Garden of Bologna.
\end{abstract}

On the 50th anniversay of the discovery of America, numerous publications have examined, from various points of view, the importance of the American plants that reached Europe. Columbus, and the navigators that followed, were said to have been looking for India and its precious spices. When it was realized that a new, previously unknown land, and not India, had been found, there were attempts to profit from this continent's medicinal plants, in particular, to wipe-out the disease that was simultaneously acquired with the discovery of America: that is, syphilis.

In the rist half of the 1500's, the interest in America's natural history was reduced to strictly medical or commercial purposes, foresaking the pursuit of fundamental and impartial knowledge. The initiatives that were begun during the first half of the 1500's were of a popular nature, though not necessarily superficial, and they attempted to quench the thirst for the new that was felt by all classes and cultures. 
The news that these initiatives provided arrived in a Europe where the culture and science, bases on the tradition of Aristotle, were reviving the Greek/Latin Classicism in the wake of the humanism of the 1400's and the Renaissance. It was these years that gave birth to the first commentary on works of natural history by Pliny, Theophrastus, and Dioscoride, authors linked to the world of the Mediterranean basin: starting with Mattioli's edition of the Dioscoride, written in 1544. The news arriving from the New World had a great impact on this recently revived mass of knowledge from the Classical era. The increased knowldege on geography resulting from the discovery of the New World rendered meaningless the schools of thought of cosmology and Ptolemaic geography, while the plants and animals that arrived from America caused disputes on the omniscience and completeness of the works of the Classical authors, who had just recently gained a large public, especially Dioscoride.

These discoveries caused a split between culture and science: while culture (meaning art, architecture, and classical studies) focussed on reviving the Greek/Roman school of thought, scientists were looking towards the East and West Indies and their resources, such as medicianl plants, precious woods, and the beautiful garden plants and fruits: in other words, they were infatuated with the exotic.

Most writings on natural history emphasized the exotic, strange, and astonishing character of the plant and animal species. For example, Clusius' work «Exoticum», 1605 , which was based on other sources that were often unverifiable and scarcely scientific; for instance, navigators, court functionaries, religious workers, and second hand recounts, all based on a small amount of evidence which was poorly conserved, fragmented, or partial' .

Clusius and other scholars were forced to reconstruct the image of a tree, for instance, based on some fruit or dried leaves, which would arrive at some Spanish port and, along with some verbal messages passed on to pharmacists and physicians, be transported to colleagues throughout Europe. The extensive autochthonous knowledge was not saved, and therefore was not transmitted to Europe, representing an irrecoverable loss of information. Only a few records of this information remain. One example is the so-called «Badiano» code, which was preserved at the Papal library in the Vatican (now in Mexico), and which collected all botanical and pharmalogical information regarding the Mexican plateau. Another herbal, which was illustrated with text, collected information, if not on natural resources, at least on the plants used in indigenous medicine and their cultivation.

For a long time, the American alimentary species were not valued as an integral part of the European diet, but only regarded as strictly ornamental plants. The potato

I See Ubrizsy \& Heniger (1983). 
and the sunflower are two weel-know examples of this phenomenon, which was in part due to the false concept of the superiority of the Old World culture.

Along with the image of the New World that was detested in the eyes of 16th Century Europeans, who pictured it as an immense treasure chest overflowing with precious novelties and amazing wonders, we must also remember that Columbus had already given his impressions on the richness and beauty of the landscape of the lands that he discovered, beauty that words could not describe. Voyagers who came after Columbus also spoke of a nature that was flourishing, rich, evergreen, colorful, extraordinarily fertile, and vast ${ }^{2}$.

The other feature that greatly astonished visitors to the New World was the radical newness of the various species with respect to the flora and fauna of Europe. The nature beyond the ocean was characertized by exuberance and diversity, and it was mainly these characteristics that brought back the idea of the existence of monsters: America, with its extraordinarily abundant nature was a land perfectly suitable for monstruous organisms.

The New World was imagined as a land of wonders; news of which arrived from unreliable sources. The real cornerstone of the problem was, in fact, just that: the reliability of sources. If the news had come from trustworthy sources, such as the Classics, it would have been equivalent to first hand personal experience. Howeter, for decades, America had only been visited by persons with no authority in the scientific field ${ }^{3}$.

After this initial period of enthusiasm for news from the West, there came the problem of acknowledging the reports and either adapting the information to already existing discourses or completeley renouncing deep-rooted beliefs. Thus, milestones in the field of botany, such as the work of Brunfel published in 1530, either omitted the origins of the few American plants included or considered them as indigenous to the Orient.

Successive works, including those by Mattioli and Fuchs and Gesner, began to describe American spcies, but to a very limited extent, mainly focussing on the same narrow group of species. Though the naturalists of the 1500's generally didn't miss an opportunity to gather information on the reality of America, they were rather reluctant to analyze in-depth the knowledge obtained and to include it in their published works. This behavior, however, was not without a certain degrec of logic, if we consider that in the 1500 's, as previously mentioned, ties with medieval tradition had been recently severed, and the study of natural history was becoming and autonomous discipline as a result of the revival of Classical scientific culture. The works of Classical authors, which were at first little or completely unknown, constituted an

2 ROMEO (1954), p. 66.

3 Olmi (1992), p. 241. 
indispensible foundation, to which, little by little, additional knowledge could be added. Studying the nature of a certain geographic area consisted of finding, in that area, the species already described by ancient authors, and trying gradually, like Mattioli with the Dioscoride, to correct and to add to their knowledge, which was limited to the Mediterranean basin. European scientists, being accustomed to seeing nature through the works of Classical authors, had great difficulties in classifying American species.

Aristotle, Theophrastus, Dioscoride, and Pliny were the undisputed authorities, and if a species was not included in their works, then there were doubts as to its existence. Criticism of the Classics was based on direct observations made in the Old World, with which the ancients were somewhat familiar; thus, criticism consisted of integration and not of radical disputes ${ }^{4}$. Accepting the new American reality meant not only contesting the authority of the ancient authors, but also questioning the existing methodoligic system and the entire cultural establishment on which naturalistic research was based. The species brought from America undermined the convictions recently established in Europe with the revival of Classical culture. By contrast, the land of the Rising Sun was much more assuring; in fact, many explorers, such as Prospero Alpino and Rauwolf, departed for the East to study the natural reality of Egypt, Syria, Cyprus, etcetera., representing a sort of compromise. In this manner, Gesner, for instance, assigned African origins to marigolds, an American species used for decorative purposes, and which was described as Flos Africanus in the botanical works of Dodoens, Lobel, and all others, with the exception of Cordus, who recognized its origins and labelled the plant Tanacetum Peruvianum, due to its resemblance to other species of Tanacetum known in Europe. A similar case was that of the cactus form of Euphorbia, which was characteristic of Mexico yet described by Dodoens as an African plant already known by Pliny, despite the fact that in a work by Lobel, published seven years earlier, the species was recognized as having Peruvian origins, though its description included comments by Galeno and Discoride.

In these botanical works the American species were mingled with those from Europe with no particular emphasis placed on them. They were classified based on similarities and analogies to species that were already well-documented. For instance, the sunflower was classified with the name Chrysanthemus peruvianum and was treated among the species belonging to the modern group of cocmposites. Tobacco was treated as Hyosciamus peruvianus, included with the European species showing similar characteristics, and confused with the American and Asian species of modern datura; the Mechoacan was grouped with the European species of the modern Convolvulacee with the name Convolvulus mechoacan; and the modern American agave,

4 Olmi (1992), p. 241. 
which for morphological similarities to the African species of aloe, was described with the name Aloe americana. When the plant was so unfamiliar that there was no possibility of grouping it with other known species, it was included in the last chapter of the botanical volume with other entities that were not well-defined.

We can therefore affirm that in this period, personal experience began to prevail over oral and written treatment; the inability to directly observe the various species and the lack of scientist's personal experience, due to the material difficulties in reaching America in the 1500's, resulted in the disproportionate quantity of information provided by explorers, navigators, etc., of which only a relatively scarce amount was published in works of natural history.

We should consider, however, that Columbus and his companions landed in an area of tropical vegetation and came into contact with species that had never been seen in Europa, while during successive explorations, the colonists that arrived in Chile, for example, could sincerely say that they had found environments physionomically identical to those in southern Spain. In fact, the evergreen surrounding areas of Santiago were typically Mediterranean and differed only in the taxonomic quality of the species and not in the physionomy. These similarities may have created additional confusion in determining whether the species from the New World were undocumented or unknown.

There were even further difficulties with respect to American spcies. One of these was the confusion, or better yet, the unclear distinction between the species coming from the East Indies and those from the West Indies, which were easily mixed up in the Portugese and Spanish ports under the name «Indiis». Even scientists such as Clusius, Dodoens, and even Linaeous were deceived, classifying, for instance, our Psoralea dentate as Trifolium americanum, which today is known to be a Mediterranean spcies.

Another source of possible confusion was the European and non-European spcies, for example indigo, banana, and sugar cane which were important in America shortly after its discovery, in that they were cultivated for plantations; after a few years, given their diffusion and thriving growth, they were believed to be indigenous.

The uncertainty shown by botanists of the 1500's was also due to the fact that they were fully able to recognize previously known species among some American plants. This was the case for indica cane or mango (mangifera indica), species that are today referred to as pantropical.

Certain botanical works, such as that by the French botanist Dalechamps, included detailed descriptions similar to those found in floristic works of the 19th Century, which repeatedly referred to the name (equivalent to the nomenclature), to the other species included in that genus (that is, the taxonomy), the place of origin and type of environment (that is, the phenology) and finally to the medicinal properties and other uses (equivalent to pharmacology and ethnobotany in modern texts). 
However, even texts such as these did not clearly describe the plants from the New World, citing them at the back of the work in a chapter dedicated to exotic flora, intermingled with African and Asian species.

The numerous contemporary works published for the year of Columbus have recounted that the Spanish Court, after losing hope in the discovery of gold «at will», promoted an exploration campaign with the aim of finding medicinal plants in Mexico, commissioning the physician and naturalist Hernandez, who embarked in $1570^{5}$.

None of these celebrated works, however, mention the great Italian scientist, Ulisse Aldrovandi, which brings us to further important considerations. The Bolognesse Aldrovandi, enthralled by the newness and infinite variety of the arrivals from America, systematically collected all writings referring to American nature and attempted to obtain the most complete collection of information, samples, drawings, paintings, and engravings from the courts, from colleagues, and from friends, for his museum and university botanical garden ${ }^{6}$. Having attested to the confusion and scarce scientific value of the information provided by the works of authors like Lopez de Gomara and Oviedo, Aldrovandi, beginning in 1559 (fifteen fifty nine), decided to put himself at the disposal of the King of Spain in order to organize an expedition to America. The goal of the expedition was to methodically describe and classify the plants and animals, as he wrote in his unpublished manuscripts, which is currently preserved in the library of the University of Bologna. According to Aldrovandi's manuscript, illustrators and writers were to accompany the scientists on this purely scientific and naturalistic journey in order to capture the images of America's landscapes and organisms, samples of which would be brought to Europe to be introduced into the herbariums of zoological collections, from which seeds would be taken to cultivate the plants in botanical gardens. The aim of the voyage is outlined in concrete and concise terms and was as follows: to describe, fix the image of, and sample all species observed so that they may be classified and compared to currently known species and to store them in order that they be available for additional study, without being at the mercy of tales recounted by voyagers who are not always sincere and who are often incapable of understanding the reality that they have seen ${ }^{7}$.

Though Aldrovandi did not hope to have any help from Philip the Second, his manuscripts, museum, iconographic collection, and herbal, which are currently preserved at the University of Bologna, bear witness to his knowledge of more American species than any other scientist who was his contemporary. His herbal includes descriptions of such plants as Fragaria virginiana ${ }^{8}$, Nicotiana glauca, Phaseolus

\footnotetext{
5 See Capocaccia et al. (1991). Gentile (1991). ? (1992).

6 See Cermenati (1906)

7 Olmi (1992), p. 246.

8 See BALDINI \& RosATI (1992).
} 
coccineus, Thuya occidentalis, Mirabilis jalapa, Schinus molle ${ }^{9}$, and even Opuntia ficus-indica ${ }^{10}$, spcies without which the Italian-Mediterranean landscape would today be unimaginable.

The great novelty of Aldrovandi's work, however, lies in the fact that he attempted to provide explanations for the great richness of species, many of which were unknown at the time. His words also anticipate concepts of bio-geography expressed only in the Nineteenth Century, specifically: «The lands discovered have a climate that is different from our own and therefore, the things that are born there (that is, plants and animals) are completely different with respect to those that are born in Europe.» ${ }^{11}$ These words clearly show traces of a concept of biodiversity that correlates the diversified floristic richness with the climate, a correlation that to some extent was sensed by Hypocrites, Theophrastus, etc. but which, in a limited way, regarded the explanation of the great fertility of Asia with respect to the Europe of the Hellenic world.

When Aldrovandi, in 1588 presented his body of work, which included a total of 100 works, of which only several were printed in the zoological field during the scientist's lifetime, he demonstrated that he had compiled a work that also described the various parts of the world through «natural things» that were born there ${ }^{12}$; today, we call this type of work a biogeographical treatise. The work consisted of four volumes, each one dedicated to the four great continents: Europe, Asia, Africa, and the fourth to the New World, product of 34 long years of observation and collected information. Aldrovandi wanted these volumes to be used for gardens, botanical gardens, and both public and private museums, which in that period were becoming increasingly common.

Evidently, there no longer existed the practice of attempting to categorize plants from America by idntifying them with those previously documented by the Ancients. Aldrovandi had overcome the error of extrapolating at any cost the experiences of European nature to the non-European territories and classifying these species by assigning them names of previously documented organisms: for new species, he preferred to use the Spanish name, as in the case of "Quoayand colorado, Mamei» which he identified as Persea, or in the case of «Coa muchil colorado», identified by the name Gladitsia triacanthos ${ }^{13}$. Otherwise, he adopted the indigenous name such as Hatoxiloxochitl (identifiable as Cassia spectabilis) ${ }^{14}$. The new entities reaching

\footnotetext{
9) See UBRIZSY (1993).

10) See BALdini (1990).

11 Olmi (1992), pp. 255-6

12 See Mattirolo (1897).

13 See UbrizSY (1993).

14 Ibidem.
} 
Europe with their indigenous and Spanish names, were also accepted in the Linnaean nomenclature, such as sassafras (Sassasfras albidum), molle (Schinus molle), guatacan (Guaiacum officinale), and zapote (Pouteria zapote) ${ }^{15}$.

The conclude, I would like to recount the impact of American plants on the art of gardening, which was very much in vogue during the Renaissance, and which transformed the alimentary plants from America into plants to be acclimatized for ornamental purposes in Europe. The gardens, according to man's will, hosted the greatest biodiversity possible on an extension of land which was at times very limited. The scientists attempted to obtain the greatest number of seeds possible from the new lands so that they could directly examine the examples cultivated in their botanical gardens. Since the process of acclimatization is based on knowledge of climate and other environmental parameters of the plant's place of origin, growing the American species in botanical gardens resulted in the beginning of a bio-blimatolgic-ecologic study that was later fully realized with the expedition of Humboldt ${ }^{16}$.

15 BALDini \& TAGLIATERRI (1990), p. 56.

16 See Ubrizsy (1990). 
THE INFLUENCE OF NEW WORLD SPECIES ON THE BOTANY OF THE $16^{\text {TH }}$ CENTURY

\section{BIBLIOGRAFÍA}

BALDINI, E. (1990), «Fruits and fuit trees in Aldrovandi's "Iconographia Plantarum"», Advances in Horticultural Science, 4, 61-73.

Baldini, E. \& TAGLiAferRI, M. C. (1990), Matrici inedite dell'Iconografia dendrologica di Ulisse Aldrovandi, Accad. Scienze Istitudo di Bologna, memorie, Bologna.

Baldini, E. \& Rosati, P. (1992), «The strawberries of Ulysses Aldrovandi», Advances in Horticultural Science, 2, 59-61.

Capocaccia Orsini, L.; Doria, G., \& Doria, G. (ED. s) (1991), 1492-1992, Animali e Piante dalle Americhe all'Europa, Genova.

Cermenati, M. (1906), «Ulisse Aldrovandi e l'America», Ann. di Bot. (Roma), 4 (4), 313-366

Cugurra, F. (1991), «Dalle Americhe il dopo Colombo: piante medicinali in Europa», Atti del Convegno Internazionale «Scambi floristici fra vecchio e Nuovo Mondo, riflessi agro-selvicolturali e impatti naturalistico-ambientali e paesaggistici», Genova, 22-23 aprile 1991, 169-76.

DE Toni, G. B. (1908), «Illustrazione del secondo volume dell'Erbario di Ulisse Aldrovandi», Atti R. Ist. Veneto Scienze, Lettere e Arti, 67, 523-634.

DE Toni, G. B. (1908), «Illustrazione del terzo volume dell'Erbario di Ulisse Aldrovandi», Malpighia, 22, 209-310.

DE TonI, G. B. (1911), «lllustrazione del quarto volume dell'Erbario di Ulisse Aldrovandi», Atti R. Ist. Veneto Scienze, Lettere e Arti, 7l, 155-214.

Frati, L. (1907), Catalogo dei manoscritti di Ulisse Aldrovandi, Bologna.

Garbari, F. (1991), «Luca Ghini a Pisa, cardine della cultura botanica del XVI secolo», Museologia scientifica, 8 (3-4), 223-236.

GeNTILE, S. (ed.) (1991a), Atti del Convegno Internazionale «Scambi floristici fra Vecchio e Nuovo Mondo, riflessi agro-selvicolturali e impatti naturalistico-ambientali e paesaggistici», Genova, 22-23 aprile 1991, Genova.

GENTILE, S. (1991b), «La componente floristica americana in Italia: considerazioni generali ed esempi di particolari impatti ambientali e paesaggistici», Atti del Convegno Internazionale «Scambi floristici fra Vecchio e Nuovo Mondo, riflessi agro-selvicolturali e impatti naturalistico-ambientali e paesaggistici», Genova, 22-23 aprile 1991, 17-56.

LEIVA SÁNCHEZ, A. (1991), «El papel de los jardines botánicos neotropicales en el intercambio de plantas: pasado, presente y futuro», Atti del Convegno Internazionale «Scambi floristici fra Vecchio e Nuo Mondo, riflessi agro-selvicolturali e impatti naturalistico-ambientali e paesaggistici», Genova, 22-23 aprile 1991, 159-68.

LUNARDI, D. (1991), «I riferimenti al Regno Vegetale del Nuovo mondo nelle prime relazioni sulle nuove terre (da Pietro Martire a Hernandez)», Atti del Convegno Internazionale «Scambi floristici fra Vecchio e Nuovo Mondo, riflessi agro-selvicolturali e impatti naturalistico-ambientali e paesaggistici», Genova, 22-23 aprile 1991, 57-70. 


\section{ANDREA UBRIZSY SAVOIA}

MaugerI, G. (1991), «Piante del Nuovo Mondo infestanti nelle culture mediterranee», ibid., 147-58.

Mattirolo, O. (1897), Opera botanica di Ulisse Aldrovandi. Bologna.

MatTirolo, O. (1898), «Illustrazione del primo volume dell'Erbario di Ulisse Aldrovandi», Malpighia 12, 241-384.

Mossetti, U. (1989), «Catalogo dell'Erbario di Ulisse Aldrovandi: i campioni ritrovati negli Erbari di Giuseppe Monti e Ferdinando Bassi», Webbia 44 (1), 151-164.

Olmi, G. (1976), Ulisse Aldrovandi. Scienza e natura nel secondo Cinquecento. Trento.

Olmi, G. (1977), «Osservazione della natura e raffigurazione in Ulisse Aldrovandi (15221605)», Ann. Ist. storico italo-germanico in Trento, 3, 105-81.

OLMI, G. (1991), «"Molti amici in varij luoghi”: studio della natura e rapporti cpistolari nel secolo XVI», Nuncius, 6 (1), 3-31.

Olmi, G. (1992), L'inventario del mondo. Catalogazione della natura e luoghi del sapere nella prima età moderna. Bologna.

PICKERSGILL, B. (1977), «taxonomy and the origin and evolution of cultivated plants in the New World», Nature, 268, 591-95.

Romeo, R. (1954), Le scoperte anericane. Milano.

SacCardo, P. A. (1909), Cronologia della flora italiana. Padova.

SCARAmella Petri, P. (1954), «Illustrazione del V tomo dell'erbario di Ulisse Aldrovandi», Atti Accad. Scienze Istituto di Bologna, Memorie ser. 1, 242, pp. 5.

ToResella, S. (1992), «Le prime piante americane negli erbari del Cinquecento», Le Scienze, 281, 46-57.

Ubrizsy Savoia, A. (1975), «Contribution à la connaissance des oeuvres de Clusius», Rev. D'Hist. des Sci. 28 (4), 361-70.

Ubrizsy Savoia, A. (1988), «Medical botanical data in some less known works by Carolus Clusius» (in Hungarian), Gyògyszerészet (Budapest) 32, 367-70.

UbrizsY SAvoIA, A. (1990), «Concetti di fitosociologia ed ecologia dal XVIII-XIX secolo: G. M. Lancisi e A. von Humboldt. I.», Accad. Naz. Sci. dei XL, Scritti di Storia della Scienza, Roma, pp. 133-43.

Ubrizsy SAvoia, A. (1975), «Contribution à la connaissance des oeuvres de Clusius», Rev. D'Hist. des Sc i. 28 (4), 361-70.

Ubrizsy Savola, A. (1992/1993), «Le piante pisane nei manoscritti di Aldrovandi», Museol. sci. 9, 363-80.

Ubrizsy Savola, A. (1993), «Le piante americane nell'Erbario di Ulisse Aldrovandi», Webbia, 48 , in press.

Ubrizsy Savoia, A. \& Heniger, J. (1983), «Contribution à la connaissance des oeuvres de Clusius», «Carolus Clusius and american plants», Taxon, 32 (3), 424-35. 